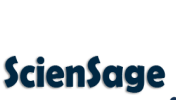

Journal of Advanced Scientific Research

Available online through https: / /sciensage.info
ISSN: 0976-9595

Research Article

DOI: $10.55218 /$ JASR. 202213115

\title{
EVALUATION OF ANTIOXIDANT, ANTIMICROBIAL ACTIVITY AND PHYTOCHEMICAL SCREENING OF AQUEOUS METHANOLIC EXTRACT OF LINUM USITATISSIMUM
}

\author{
Guna Bhushana Daddala* ${ }^{1}$, A. Swaroopa Rani ${ }^{1}$, A. Kiran kumar ${ }^{2}$ \\ ${ }^{1}$ Department of Biotechnology, (JNTUA), Jawaharlal Nehru technological university, Ananthapur, India \\ ${ }^{2}$ University college of Technology, Department of Biotechnology, Osmania University, Telangana State, India \\ *Corresponding author: daddala.gunabhushana@gmail.com
}

\begin{abstract}
The present study was carried out to evaluate the antioxidant, antimicrobial study and phytochemical assessment of $80 \%$ v/v aqueous methanol extract of Linum usitatisimum. Flax seeds (Linum usitatisimum) are an ample source of lignans, which have antioxidant properties and promisingly reduce the effects of free radicals. The antioxidant activity of the extract was determined by free radical scavenging activity using DPPH radical and the activity was in the range of 26.7\% to $98.6 \%$. The average inhibitory concentration $\left(\mathrm{IC}_{50}\right)$ was calculated. According to $\mathrm{DPPH}$ method, the $\mathrm{IC}_{50} \mathrm{value}$ of $80 \% \mathrm{v} / \mathrm{v}$ aqueous methanol extract of flax seeds was $5.56 \mathrm{mg} / \mathrm{ml}$. An in vitro antimicrobial assay by disc diffusion method was carried out. The results showed that $80 \% \mathrm{v} / \mathrm{v}$ aqueous methanol extract of seeds were effective against various test microorganisms. This paper also presents total phenolic assessment of $80 \% \mathrm{v} / \mathrm{v}$ aqueous methanol extract of flax seeds; the content was $20.91 \%$. Furthermore, $80 \% \mathrm{v} / \mathrm{v}$ aqueous methanol extract was examined for qualitative phytochemical analysis and the results illustrate the presence of alkaloids, flavonoids, phenols, glycosides, steroids, terpenoids and proteins.
\end{abstract}

Keywords: Flax, Antioxidant activity, Polyphenol, DPPH, Antimicrobial activity, Phytochemicals.

\section{INTRODUCTION}

Linum usitatissimum, commonly called as Flax, is a member of the Linaceae family [1], can be grown in every country with moderate climate. Flax becomes up to 1.2 meters tall. From June to August, flax plants carry flowers consisting of 5 petals, colored red or blue. Flax is grown for linseed oil and in European countries flax is generally used as a source of fiber [2, 3]. Flax seed contains around 30\%-40\% oil, 20\%-25\% protein, 20\%-28\% total dietary fiber and the oil contains vitamins $\mathrm{A}, \mathrm{B}, \mathrm{D}$ and $\mathrm{E}$, minerals and amino acids. Flax seed has often fallen into several categories: "functional food", "bioactive food" and an "endocrine active food" for the incidence of physiologically active food components that may provide health benefits beyond the basic nutrition [4].

Plants are used as a source of treatment for diseases since ancient times. The usage of herbal medicines grew due to their lesser side effects and natural origin. Numerous plants, parts of plants have been exploited for this purpose. The medicinal values of these plants could produce certain physiological action on the human body; this may be due to the presence of some chemical substances [5].

flax seed contains numerous bioactive compounds. Among plant foods, flax seeds have the highest content of lignans [6], largely in the form of secoisolariciresinol diglucoside; flax seed oil has a very high concentration of the essential omega-3 fatty acid alpha-linolenic acid [7]. Scientific evidences backing the consumption of flax seed enhance the prevention of some chronic diseases such as many types of cancer, diabetes, cardiovascular diseases and cerebrovascular stroke as it has a high content of omega-3, omega- 6 rich oil, $\alpha$-linolenic acid, lignans, high quality proteins and fibres that are biologically active [8]. Other bioactive compounds of flax seed are from the class of phenolic compounds, including lignans, flavonoids and phenolic acids $[9,10]$. Lignans, phenolic acids and flavonoids are preventative in the decreasing rate of tumour growth and the decreasing incidence of breast, prostate, and colon cancers [1, 11]. Also the natural antioxidants play an important role in slowing down oxidation processes by quenching free radicals, chelating catalytic metals and 
scavenging oxygen or oxidizing chain reaction [1,12-14]. The present study was carried out to study the antioxidant, antimicrobial activities and phytochemical assessment of Linum usitatisimum (flax seeds) by using $80 \% \mathrm{v} / \mathrm{v}$ aqueous methanol. Furthermore, due to its excellent nutritional profile and potential health benefits, currently it became an attractive ingredient in the diets specially designed for specific health benefits [15].

\section{MATERIAL AND METHODS}

Samples of flax seeds (whole grains) were obtained from a local store in Chennai, India. 2, 2-Diphenyl-1picrylhydrazyl (DPPH) was procured from Sigma Aldrich, Folin-Ciocalteu's reagent was purchased from LobaChem, India, as the $2 \mathrm{~N}$ reagent. All the other chemicals / reagents and solvents used in this study were purchased from Merck, India Pvt. Ltd as analytical reagent grade materials and applied without subsequent purification.

\subsection{Extraction of flax seeds}

Flax seeds were ground using a grinder; ground material was extracted with $5 \mathrm{ml}$ of $80 \%$ aqueous methanol for $0.5 \mathrm{~g}$ seed material. Extracts were obtained at room temperature using a separator set at 5000 RPM for 20 minutes. The supernatants were decanted and transferred into conical flasks. Freshly prepared extracts were tested.

\subsection{Evaluation of antioxidant activity using DPPH method}

Free radical-scavenging capacity of flax seed extracts was determined spectrophotometrically. The modified method described by Oyedemi et al (2011) was used to determine the DPPH scavenging activity of the flax extract [16]. A solution of $0.135 \mathrm{mM}$ DPPH was prepared in methanol. Different concentrations of extracts $1.5,3,6,12,24$ and 36 etc. $(0.5 \mathrm{ml})$ were mixed with $2.5 \mathrm{ml}$ of $\mathrm{DPPH}$ solution. The reaction mixture was vortexed thorough and left in the dark at room temperature for $30 \mathrm{~min}$. The absorbance was measured at $517 \mathrm{~nm}$. Ascorbic acid was used as the reference drug. The ability of the flax extract to scavenge DPPH radical was calculated from the following formula:

$\%$ DPPH inhibition $=\{(\mathrm{OD}$ of control-OD of test $) /$ (OD of control) $\} \times 100$

\subsection{Evaluation of antimicrobial activity}

2.3.1. Anti-bacterial activity of test Sample against the E.coli and Staphylococcus aureus

The samples were screened for their antibacterial activity by disc diffusion technique. Compounds were screened in vitro for their anti-microbial activity against E.coli (MTCC 443) and Staphylococcus aureus (MTCC 96) and were compared with standard drug Streptomycin $(10 \mu \mathrm{g})$. The zones of inhibition formed for the compounds against organisms were calculated. The antibacterial activities of test samples were carried out by disc diffusion method. The concentrations of $1000 \mu \mathrm{g}$ and $2000 \mu \mathrm{g}$ test samples were taken in aqueous methanol. The targeted microorganisms were cultured in Mueller-Hinton broth (MHB). The suspensions were adjusted to standard subculture dilution after $24 \mathrm{~h}$. The petri dishes that contain Muller Hinton Agar (MHA) medium were cultured with diluted bacterial strain.

Discs made of Whatman No.1, diameter $6 \mathrm{~mm}$ were presterilized and were maintained in aseptic chamber. Each concentration was injected to the sterile disc papers. The prepared discs were then placed on the culture medium. Standard drug Streptomycin $(10 \mu \mathrm{g})$ was used as a positive reference standard to determine the sensitivity of each microbial species tested. Then the inoculated plates were incubated at $37^{\circ} \mathrm{C}$ for $24 \mathrm{~h}$. The diameter of the clear zone or zone of inhibition around the disc was measured and expressed in millimeters as its anti-microbial activity.

\subsubsection{Anti-fungal activity of test Sample against the Candida albicans}

The samples were screened for antifungal activities by disc diffusion technique. Compounds were screened in vitro for their antifungal activity against Candida albicansa nd are compared with standard drug Clotrimazole. The zone of inhibition formed for the compounds against organisms was calculated.

Potato dextrose agar (PDA) was sourced for fungal cultures. The culture medium was inoculated with the fungal strains distinctly suspended in Potato dextrose broth. The samples of $1000 \mu \mathrm{g}$ and $2000 \mu \mathrm{g}$ were then applied on sterile disc. Standard antibiotic (Clotrimazole $10 \mu \mathrm{g}$ ) was used as positive control. The prepared fungal plates were incubated at $37^{\circ} \mathrm{C}$ for $72 \mathrm{~h}$. The zone of inhibition observed was measured.

\subsection{Determination of total phenolic content}

Total phenolic content of the sample was determined 
using the Folin-Ciocalteu's method with Gallic acid as standard [17].

\subsubsection{Acid Stock Solution}

Transferred $0.010 \mathrm{~g}$ of dry gallic acid into a $100-\mathrm{mL}$ volumetric flask, added $10 \mathrm{ml}$ of ethanol and diluted to volume with water.

\subsubsection{Sodium Carbonate Solution}

Tewnty $g$ of anhydrous sodium carbonate was dissolved in $80 \mathrm{ml}$ of water and boiled. Cooled the solution to room temperature, after cooling, added a few crystals of sodium carbonate and after 24 hours filtered and added water to make up to the volume $100 \mathrm{ml}(\mathrm{pH} \sim 14)$.

\subsubsection{Preparation of calibration curve}

To prepare a calibration curve, different concentrations $(0,2,3,4$, and $10 \mathrm{ml})$ of the stock solution were added into $100 \mathrm{ml}$ volumetric flasks, diluted to the volume with water. These solutions will have phenol concentrations of $0,2,4,8,16,32,64 \mathrm{mg} / \mathrm{L}$ Gallic acid. $20 \mu \mathrm{L}$ of the sample, or blank from each calibration solution were pipetted out into separate cuvettes, and added $1.58 \mathrm{ml}$ water to each cuvette, added $100 \mu \mathrm{L}$ of the Folin-Ciocalteu reagent and mixed well. After $5 \mathrm{~min}, 300 \mu \mathrm{L}$ of the sodium carbonate solution was added and mixed well. The solutions were kept at room temperature for $2 \mathrm{hrs}$. Absorbance was measured at $765 \mathrm{~nm}$ for each solution. Based on the absorbance, the concentrations of phenolics were interpreted $(\mathrm{mg} / \mathrm{ml})$ from the calibration line; then the content of phenolics in the extracts was expressed in terms of Gallic acid equivalent (mg of GA/g of extract).

\subsection{Phytochemical screening}

Phytochemical evaluation for various phytoconstituents of the extracts were undertaken using standard qualitative methods [18, 19]. The extracts were screened with the presence of biologically active compounds like alkaloids, carbohydrates, glycosides, amino acid, proteins, steroids, diterpenes, flavonoids, phenolic, tannin, etc.

To the $1 \mathrm{~mL}$ of extract, $2 \mathrm{ml}$ of Mayer's reagent was added, a dull white precipitate revealed the presence of alkaloids (Mayer's Test). $5 \mathrm{ml}$ of water was added to 1 $\mathrm{ml}$ of the extract and the tube was shaken vigorously. Copious lather formation indicates the presence of Saponins. To the $1 \mathrm{ml}$ extract, ferric chloride was added, formation of a dark blue or greenish black colour showed the presence of tannins. To $1 \mathrm{ml}$ of the extracts,
$1 \mathrm{ml}$ of concentrated $\mathrm{H}_{2} \mathrm{SO}_{4}$ was added and allowed to stand for $2 \mathrm{~min}$. a reddish colour precipitation indicates the presence of glycosides. $1 \mathrm{~mL}$ of the extract was treated with $10 \% \mathrm{NaOH}$ solution, formation of intense yellow colour indicates presence of Flavonoid. To the $1 \mathrm{~mL}$ of extract, $3 \mathrm{ml}$ of $10 \%$ lead acetate solution was added. A bulky white precipitate was formed indicating the presence of phenolic compounds. $1 \mathrm{~mL}$ of the extract was dissolved in $10 \mathrm{ml}$ of chloroform and equal volume of concentrated $\mathrm{H}_{2} \mathrm{SO}_{4}$ acid was added from the side of the test tube. The superior layer turns red and $\mathrm{H}_{2} \mathrm{SO}_{4}$ layer showed yellow with green fluorescence. This indicates the presence of steroid. $5 \mathrm{ml}$ of extract was mixed with $2 \mathrm{ml}$ of chloroform, and concentrated $\mathrm{H}_{2} \mathrm{SO}_{4}$ was carefully added to form a layer. A reddish brown colouration of the interface indicates the occurrence of terpenoids. $1 \mathrm{~mL}$ of the extract was treated separately with alc. $\mathrm{KOH}$ solution. Manifestation of colours ranging from red to blue indicates the presence of Quinones. To $2 \mathrm{ml}$ of the extract, $0.1 \mathrm{ml}$ of Conc. $\mathrm{HCl}$ and $1 \mathrm{ml}$ of Ninhydrin reagent was added and heated for $5 \mathrm{~min}$ at $100^{\circ} \mathrm{C}$. Formation of the bluecoloursignifies the presence of protein.

\section{RESULTS AND DISCUSSION}

\subsection{Evaluation of antioxidant activity using DPPH method}

The study showed the ability of the flax seed,its free radical scavenging activity, also expressed by the antioxidant activity was from $26.7 \%$ to $98.6 \%$. The lowest concentration $1.5 \mathrm{mg} / \mathrm{ml}$ corresponded to $26.69 \pm 1.46812 \%$, while for the highest concentration $60 \mathrm{mg} / \mathrm{ml}$ it was $98.52 \pm 0.22782 \%$. However, the graph was linear from $1.5 \mathrm{mg} / \mathrm{ml}$ to $24 \mathrm{mg} / \mathrm{ml}$, presented in Table 1. The experiment was continued further in $36,48 \mathrm{mg} / \mathrm{ml}$, the activity was 96.53 $0.22782 \%, 97.65 \pm 0.27158 \%$, correspondingly.

Table 1: Percentage scavenging of 1,1-Diphenyl2-Picrylhydrazyl radical

\begin{tabular}{cc}
\hline $\begin{array}{c}\text { Concentration of } \\
\text { Extract } \mathbf{~ m g} / \mathbf{m L}\end{array}$ & $\begin{array}{c}\text { Percentage scavenging } \\
\text { activity }\end{array}$ \\
\hline 1.5 & $26.69 \pm 1.46812$ \\
\hline 3 & $36.77 \pm 1.06078$ \\
\hline 6 & $43.65 \pm 1.38889$ \\
\hline 12 & $61.38 \pm 0.77058$ \\
\hline 24 & $84.79 \pm 0.78918$ \\
\hline 36 & $96.53 \pm 0.22782$ \\
\hline
\end{tabular}

The concentration required for $50 \%$ DPPH reduction $\left(\mathrm{IC}_{50}\right)$ was $5.56 \mathrm{mg} / \mathrm{mL}$, which was calculated from the 
linear regression equation: $\mathrm{y}=\mathrm{mx}+\mathrm{c}$, where $\mathrm{y}=2.160 \mathrm{x}$ $+26.69, \mathrm{R}^{2}=0.943$, are presented in Fig. 1 . The $\mathrm{IC}_{50}$ value is defined as the concentration of the extract required for $50 \%$ scavenging of radicals. Lesser $\mathrm{IC}_{50}$ value corresponds to a higher antioxidant activity [20].

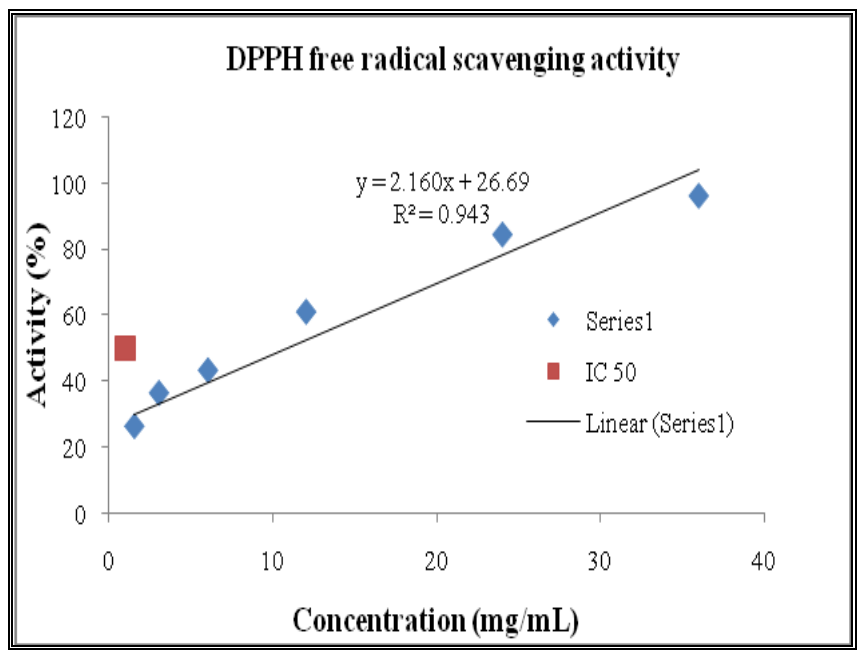

Fig. 1: Antioxidant activity of flax seeds based on DPPH method

According to Katarzyna et al, 2014, IC $_{50}$ values for defatted, non-defatted flax seed extracts were 35.5 $\mathrm{mg} / \mathrm{ml}$ and $29.9 \mathrm{mg} / \mathrm{ml}$ respectively [21]. However, as per the studies of Amin and Thakur, the percentage scavenging of DPPH radical of non-defatted flax seeds were at the lowest concentration; $100 \mu \mathrm{g} / \mathrm{ml}$ corresponded to $32.33 \%$, while for the highest concentration; $500 \mu \mathrm{g} / \mathrm{ml}$ was $82.53 \%$. The $\mathrm{IC}_{50}$ value of ethanolic extract of flax seeds was $256.313 \mu \mathrm{g} / \mathrm{ml}$ [22]. Gaafar et al., also have reported that different defatted flax seeds cultivars possessed antioxidant, scavenging activity in the field from $5.57 \pm 0.28 \%$ to $9.05 \pm 0.76 \%$, which corresponded to the lowest concentration of flax seeds $5 \mu \mathrm{g} / \mathrm{ml}$. The highest concentration of defatted flax seeds $50 \mu \mathrm{g} / \mathrm{ml}$ was characterized by percentage scavenging of DPPH radical ranging from $55.17 \pm 0.56 \%$ to $88.56 \pm 0.28 \%$. These differences between flax seed cultivars may be caused by country of origin of testing seeds of flax [23].

\subsection{Evaluation of antimicrobial activity}

The zones of inhibition shown by $80 \% \mathrm{v} / \mathrm{v}$ of an aqueous methanol extract of flax seeds are effective against Staphylococcus aureus, Escherichia coli, the zone of inhibition observed for $2000 \mu \mathrm{g}$ concentration was $8 \mathrm{~mm}$ for both the organisms, whereas $1000 \mu \mathrm{g}$ concentration did not show any activity (Table 2). However, both the concentrations did not show any activity against Candida albicans (Table 3). Plant-derived phytochemicals are a wide group of chemical compounds synthesized in the secondary metabolism. Alkaloids, phenolic compounds, and flavonoids originate naturally in plants, have been established in vitro to have antimicrobial activities [24, 25]. Our results are in concurrence with the fact that the phyochemicals are known to exhibit antibacterial activity, also with the results reported by Andreea I. PAG et al. (2014) [26].

Table 2: Antibacterial activity

\begin{tabular}{ccc}
\hline \multirow{2}{*}{ Sample } & \multicolumn{2}{c}{ Zone of Inhibition ( mm) } \\
\cline { 2 - 3 } & S. aureus & E. Coli \\
\hline Extract $(1000 \mu \mathrm{g})$ & - & - \\
\hline Extract $(2000 \mu \mathrm{g})$ & 8 & 8 \\
\hline Streptomycin $(10 \mu \mathrm{g})$ & 21 & 24 \\
\hline
\end{tabular}

Table 3: Antifungal activity

\begin{tabular}{cc}
\hline \multirow{2}{*}{ Sample } & Zone of Inhibition $(\mathbf{m m})$ \\
\cline { 2 - 2 } & Candida albicans \\
\hline Extract $(1000 \mu \mathrm{g})$ & - \\
\hline Extract $(2000 \mu \mathrm{g})$ & - \\
\hline Clotrimazole $(10 \mu \mathrm{g})$ & 16 \\
\hline
\end{tabular}

\subsection{Determination of total phenolic content}

Total phenolic content of the samples was calculated using standard calibration curve of Gallic acid (standard curve equation: $y=0.0247 x+0.2124$ and $\mathrm{R} 2=0.9972$ ) and is presented in Fig. 2. The phenolic content in the $80 \%$ aqueous methanol extract of Flax seeds was found to be $21.54 \mathrm{mg} / \mathrm{g}$. The values obtained are expressed as $\mathrm{GAE} / \mathrm{g}$ of extract (GAE = Gallic Acid Equivalent). Total polyphenol contents were estimated by FolinCiocalteu colorimetric method. The absorption of which is the maximum in the wavelength range of 700 $\mathrm{nm}$ to $750 \mathrm{~nm}$, proportional to the amount of polyphenols present in the extracts [27].

The results obtained are higher than the values reported for $70 \%$ acetone $(12 \mathrm{mg} / \mathrm{g}), 70 \%$ ethanol $(15.5 \mathrm{mg} / \mathrm{g})$, $70 \%$ methanol $(13.5 \mathrm{mg} / \mathrm{g})$ and water $(11.5 \mathrm{mg} / \mathrm{g})$ [28]. Whereas same as the value reported $(21.52 \mathrm{mg} / \mathrm{g})$ by Amin and Thakur (2014) [22].

Flax holds three types of phenolic compounds: phenolic acids, flavonoids and lignans. The majority of phenolics are believed to exhibit antioxidant and anticancer effects in humans [29, 30]. Flax contains about 8-10 g of total phenolic acids per kilogram of flax. Flax is a significant 
source of a lignan called secoisolariciresinol diglucoside (SDG), which can be found in amounts ranging from 1 $\mathrm{mg} / \mathrm{g}$ of seed to nearly $26 \mathrm{mg} / \mathrm{g}$ of seed [31].

\section{Calibration curve for Total phenolic content}

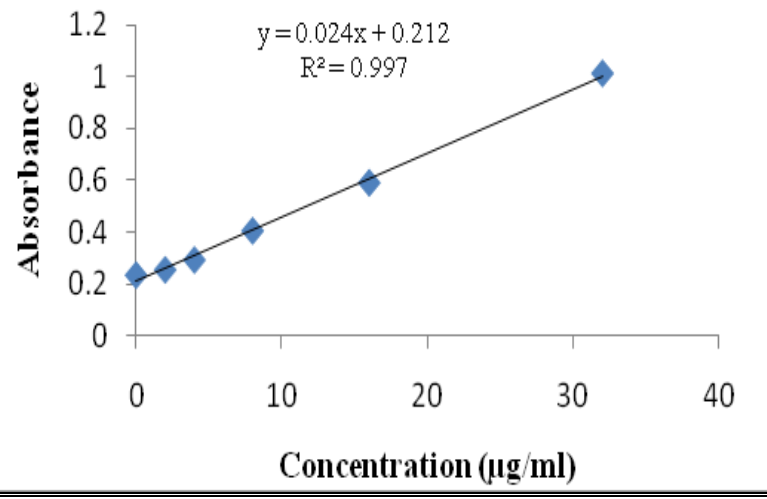

Fig. 2: Calibration curve of Gallic acid

\subsection{Phytochemical screening}

The results of preliminary qualitative phytochemical study are depicted in Table 4. The study carried out on $80 \%$ aqueous extract of flax seed, shows the presence of phytochemicals such as alkaloids, flavonoids, phenols, glycosides, steroids, terpenoids and proteins while saponnins, tannins and quinones were absent.

Hanaaet al. (2017) carried out the phytochemical screening in four different extracts of flax seed. $70 \%$ acetone extract of flax seed showed the absence of tannins, $70 \%$ ethanol and water extracts showed the absence of saponnins, tannins, alkaloids and glycosides, $70 \%$ methanol showed the absence of only saponnins [28]. Amin and Thakur (2014) reported that phytochemical analysis of ethanol extract of flax seeds showed the absence of saponins, sterols, and glycosides [22]. Whereas Nazir et al. (2012) reported the absence of tannins, glycosides, reducing sugars and steroids in the methanol extract of flax seeds [32].

Table 4: Phytochemical analysis of $80 \% \mathrm{v} / \mathrm{v}$ aqueous methanol

\begin{tabular}{ccc}
\hline Name of the analyte & Name of the reagent / tests & $\mathbf{8 0 \%} \mathbf{A q}$ Methanol Extract \\
\hline Alkaloids & Mayer's Test & + \\
\hline Saponins & Distilled water & - \\
\hline Tannins & $5 \%$ Ferric chloride & - \\
\hline Flavonoids & Alkaline reagent test & + \\
\hline Phenols & Lead acetate test & + \\
\hline Glycosides & Conc. H2SO4 test & + \\
\hline Steroids & Chloroform, Acetic acid, $\mathrm{H}_{2} \mathrm{SO}_{4}$ & + \\
\hline Terpenoids & Salkowski test & - \\
\hline Quinones & Alc. KOH & + \\
\hline protein & Ninhydrine test & + \\
\hline
\end{tabular}

$(+)$ indicates presence; (-) indicates absence

\section{CONCLUSION}

This study evaluates that the antioxidant, antimicrobial study and phytochemical assessment of $80 \%$ aqueous methanol extracts. $80 \%$ aqueous extracts showed better antioxidant activity compared to methanol, ethanol and chloroform extracts. Whereas the extract did not show any activity against Candida Albicans. Further exploration may be essential to investigate the activities of flax seed thoroughly to understand and utilize the novel benefits for human health.

\section{Conflict of interst}

None declared

\section{REFERENCES}

1. Anwar F, Przybylski R. Acta Scientarium Polonorum Technologia Alimentaria, 2012; 11:293-301.
2. Grishanov SA, Harwood RJ, Booth I. Industrial Crops and Products, 2006; 23:273-287.

3. Ossola M, Galante YM. Enzyme andMicrobial Technology, 2004; 34:177-186.

4. Hasler CM, Kundrat S, Wool D. Curr. Atheroscler.Rep, 2000; 2:467-475.

5. Edeoga H, Okwu D, Mbaebie B. Afr J Biotechnol, 2005; 4(7):685-688.

6. Milder IE, ArtsIC, Vande PB, Venema DP, Hollman PC. Br. J. Nutr, 2005; 93(3):393-402.

7. Johnsson P. PhD Thesis. Swedish Univeristy of Agricultural Sciences, Uppsala, Sweden, 2009.

8. Bernacchia R, Preti R, Vinci G. Austin J Nutri Food Sci, 2014; 2(8):2381-8980

9. Basavaraj M. Agriculturae Conspectus Scientificus (ACS), 2009; 67-72. 
10. Lowcock EC, Cotterchio M, Boucher BA. Cancer Causes Control, 2013; 24:813-816.

11. HuCh, Yuan YV, Kitts DD. Food and Chemical Toxicology, 2007; 45:2219-2227.

12. Badarinath A, RAO KM, Chetty CM, Ramkanth S, Rajan T, Gnanaprakash K. Int. J. PharmTech Res, 2010; 2(2):1276-1285.

13. Velioglu YS, Mazza G, Gao L, Oomah BD. J. Agric. Food Chem, 1998; 46:4113-4117.

14. Shahidi F, HO CT. Phenolic Compounds in Foods and Natural Health Products. Washington, DC: American ChemicalSociety; 2005.

15. Oomah BD. J Sci Food Agric, 2001; 81:889-894.

16. Oyedemi SO, Afolayan AJ. International Journal of Pharmacology, 2011;7(2):48-256.

17. Mohammad Amzad Hossain, Khulood Ahmed Salim, AL-Raqmi., Zawanhamood AL-Mijizy, Afafmohammed Weli, Qasim A-Riyami. Asian Pacific Journal of Tropical Biomedicine, 2013; 1691(13):60142.

18. Khaled Altwair.Salem edrah. Curr. Chem. Pharm. Sc, 2015; 5(2):47-55.

19. Alachaher FZ, Dali S, Dida N, Krouf D. International Food Research Journal, 2018; 25(1):7582.

20. Vulic JJ, Tumbas VT, Savatovic SM, Dilas SM, Ćetkovic GS, Ĉanadanovic-Brunet JM. Actaeriodica Technologica, 2011; 42:1-288.

21. Katarzyna Brodowska, Rikcatthoor, Agnieszka Joannabrodowska, Marzena Symonowicz, Elzbieta Lodyga-Chruscinska. Albanian j. agric. sci, 2014; 13(2):16-23.
22. Amin $\mathrm{T}$, Thakur M. International Journal of Current Microbiology and Applied Sciences, 2014; 3(4):465481.

23. Gaafar AA, Salama ZA, Askar MS, El-Hariri DM, Bakry BA. International Journal of Pharmaceutical Sciences Review and Research, 2013; 47:291-297.

24. Barbieri R, Coppo E, Marchese A, Daglia M, Sobarzo-Sanchez E, Nabavi SF. Microbiol Res, 2017; 196:44-68.

25. Djeussi DE, JNoumedem AK, Seukep JA. BMC Complementary and Alternative Medicine, 2013; 13:164.

26. Andreea I, Pag Dana G, Radu Dan, Dră Gănescu, MarcelI. Popa, Cecilia, Sirghie. Cellulose Chem. Technol, 2014; 48 (3-4): 265-273.

27. EI-Haci IA, Didi A, BekkaraFA, Gherib M. Scientific Study Res, 2009; 10(4):1582-5401.

28. Hanaa MH, Ismail HA, Mahmoud ME, Ibrahim HM. Minia J. of Agric. Res. \& Develop, 2017; 37:129140.

29. Duangjai Tungmunnithum, Areeya Thongboonyou, Apinan Pholboon, AujanaYangsabai. Medicines (Basel), 2018; 5(3):93.

30. Barbary OM, SohaimyEl, SA, El-Saadani MA, Zeitoun AM. Research Journal of Agiculture and Biological Sciences, 2010; 6:247-256.

31. Morris DH. In: Flax Council of Canada: DHMorris, 4th edition, Winnipeg, MB: Canada, 2007; 9:21.

32. Nazir Ahmad, Zia-ur-Rahman, Nafees Akhtar, Shujait Ali. Pak Vet J, 2012; 32(2):211-215. 